\title{
Ambient Air and Hole Transport Layer Free Synthesis: Towards Low Cost $\mathrm{CH}_{3} \mathrm{NH}_{3} \mathrm{PbI}_{3}$ Solar Cells
}

\author{
Muhammad Imran Ahmed, ${ }^{1}$ Hareema Saleem, ${ }^{1}$ Ahmed Nawaz Khan, ${ }^{1}$ and Amir Habib ${ }^{1,2}$ \\ ${ }^{1}$ School of Chemical and Materials Engineering, National University of Sciences and Technology, Islamabad 44000, Pakistan \\ ${ }^{2}$ Department of Physics, College of Sciences, University of Hafar Al Batin, P.O. Box 1803, Hafar Al Batin 31991, Saudi Arabia \\ Correspondence should be addressed to Muhammad Imran Ahmed; imranrahbar@scme.nust.edu.pk \\ and Amir Habib; amirhabib@scme.nust.edu.pk
}

Received 10 March 2016; Accepted 14 April 2016

Academic Editor: Yongqing Cai

Copyright (C) 2016 Muhammad Imran Ahmed et al. This is an open access article distributed under the Creative Commons Attribution License, which permits unrestricted use, distribution, and reproduction in any medium, provided the original work is properly cited.

\begin{abstract}
Perovskite absorbers have witnessed a remarkable efficiency increase in last couple of years. To meet the commercialization challenge, reduced cost and improved efficiency are the two critical factors. We report on a hole transport layer free device synthesized under ambient air conditions of high humidity of $50 \%$ using $\mathrm{TiO}_{2}$-graphene oxide nanocomposite as electron selective contact. The devices achieved a power conversion efficiency of $5.9 \%$. We introduce a novel synthesis route for $\mathrm{TiO}_{2}$-graphene oxide (GO) composite allowing superior charge transport properties. Incorporation of $\mathrm{GO}$ in $\mathrm{TiO}_{2}$ allows achieving higher power conversion efficiencies while working under ambient air conditions. Ambient air synthesis with hole transport free architecture has the potential to reduce the cost of this technology leading to commercial viability.
\end{abstract}

\section{Introduction}

Ability to harness energy has ushered in the current age of development. Intricate interdependence of our ecosystem has resulted in considerable damage to environment by our use of fossil fuels. Depleting resources and ever increasing costs have reinvigorated the efforts to find sustainable alternatives. Heralded as a major scientific breakthrough in 2013, perovskite absorbers based solar cells have achieved major milestones in a span of few years on the back of intense research effort with a certified efficiency at $20.1 \%$ [1]. Perovskite absorbers have all the right ingredients, high extinction coefficient $[2,3]$, charge carrier mobility [4], long diffusion lengths [5], ambipolar charge transport properties [6], earth abundant materials, and, to cap it all, low temperature solution processability, to make them the green technology of tomorrow.

Developed as a solid state Dye-Sensitized Solar Cell (DSSC) $[7,8]$, perovskites have evolved as a new class of solar cell. Mesoporous [9], mesostructured [6], and planer architecture [10] have been explored. Scaffolds of $\mathrm{TiO}_{2}$ were replaced by inert $\mathrm{Al}_{2} \mathrm{O}_{3}$ and then by zirconia demonstrating the ability to transport electrons by perovskite absorbers [11-13].
Electron beam induced current studies have concluded that hole diffusion length is longer than electron diffusion lengths for devices with $\mathrm{TiO}_{2}$ as electrons selective contact [14]. The ability to transport holes was established by demonstrating devices employing only one selective contact for electrons [15]. Processing has evolved from one-step spin coating [16] to two-step sequential deposition [17], vapor assisted [9], coevaporated [18] and numerous other techniques to achieve the optimum film morphology. Efforts have also been directed at evolving methods for processing under ambient conditions of high relative humidity with considerable success [17]. $\mathrm{TiO}_{2}$ has been a material of choice for electron selective contact applications. A wide band gap semiconductor has been extensively investigated owing to its low cost, electrochemical stability, and facile processing [19]. An important aspect of improving efficiency in these devices is to improve the charge carrier mobility by modifying $\mathrm{TiO}_{2}$ by substitutions with $\mathrm{Y}^{3+}, \mathrm{Al}^{3+}$, or $\mathrm{Nb}^{5+}$ into $\mathrm{TiO}_{2}$ [20-22] or by using titania nanorods and nanowires and $\mathrm{ZnO}$ nanorods [23-25].

Electron transport shortcoming of $\mathrm{TiO}_{2}$ can be addressed by employing graphene owing to its remarkable electron transport properties. Thermal stability, optical transparency 
and outstanding conductivity, and charge carrier mobility afford the possibility of improving the optoelectronic devices in all aspects [26-29]. GO and reduced GO (rGO) have been investigated for wide ranging applications in memory devices [30], transistors [31], biosensors, and solar cells [32]. Several studies have concluded the effectiveness of utilization of GO and rGO for optimization of DSSCs [33-35]. A recent report has established that incorporation of graphene in $\mathrm{TiO}_{2}$ reduces the series resistance and improves the energy scheme in planar geometry solar cells [36].

Hole selective contact free device geometry has the potential to afford reduced cost by avoiding the expensive Hole Transport Materials (HTMs). High certified efficiencies for this configuration bode possibility to develop this technology for commercial application [37-39]. One limiting point is the stringent requirement of environmental control needed to process these devices. Thus obtaining hole transport layer (HTL) free devices while processing under ambient air conditions of high humidity could open the possibility of reduced cost commercial viability of this technology.

Here we combine HTL free architecture with ambient air synthesis of high relative humidity to afford a possibility of manufacturing cost optimization. The architecture used a $\mathrm{TiO}_{2}$ electron transport layer with $\mathrm{CH}_{3} \mathrm{NH}_{3} \mathrm{PbI}_{3}$ absorber resulting in an efficiency of $5.9 \%$. Impedance spectroscopy was employed to evaluate the series and shunt resistance values. Graphene was incorporated into $\mathrm{TiO}_{2}$, using a novel synthesis technique to synthesize a nanocomposite for electron selective contact. Incorporation of this composite reduces series resistance and improves the shunt resistance increasing both Fill Factor (FF) and efficiency. Incorporation of GO in titania composite had an added advantage of improving the stability of the device. Since titania interface with $\mathrm{CH}_{3} \mathrm{NH}_{3} \mathrm{PbI}_{3}$ is reported to be detrimental due to titania activation under Ultraviolet (UV), red shifting the titania band gap can help offset this deterioration. Effect of temperature on the performance of solar cell was investigated by conducting impedance spectroscopy at elevated device temperature of $40^{\circ} \mathrm{C}$ and $60^{\circ} \mathrm{C}$.

\section{Experimental Methods}

2.1. Materials. All the chemicals except $\mathrm{CH}_{3} \mathrm{NH}_{3} \mathrm{I}$ were purchased from sigma Aldrich and were used without further processing. $\mathrm{CH}_{3} \mathrm{NH}_{3} \mathrm{I}$, (MAI) was sourced from Dysol (MS101000-50). Indium doped tin oxide (ITO) was used as front contact. At $10 \mathrm{~mm} \times 10 \mathrm{~mm}$ it had a resistivity of $15 \Omega / \mathrm{cm}$. ITO coated slides were detergent cleaned, washed with flowing ultrapure water, and ultrasonicated in ethanol for $20 \mathrm{~min}$. They were subsequently dipped for one minute in piranha solution, rinsed in flowing ultrapure water, and dried by blowing hot air.

2.2. Experimental Details. Titania nanoparticles were synthesized by sol gel route. Titanium isopropoxide (<97\%), 2methoxyethanol (99.9+\%), and ethanolamine (99+\%) were mixed in 1:4:0.5 molar ratio. The mixture was refluxed in a three-necked flask in an inert environment and stirred at room temperature for $1 \mathrm{hr}$ and $80^{\circ} \mathrm{C}$ for $1 \mathrm{hr}$ and finally the temperature was raised to $120^{\circ} \mathrm{C}$ for $2 \mathrm{hr}$ under constant stirring. Light yellow color of the sol indicated the dissolution of isopropoxide precursor in methoxyethanol solvent aided by ethanolamine as linker. Modified hummers method [40] was used to synthesize graphene oxide from graphite flakes average +100 mesh $(\geq 75 \% \mathrm{~min})$.

Devices were synthesized by spin coating titania over precleaned ITO coated glass slides at $2500 \mathrm{rpm}$ for $20 \mathrm{~s}$. $\mathrm{TiO}_{2}$ coated slides were dried in oven at $500^{\circ} \mathrm{C}$ for $2 \mathrm{hr}$ with a heating rate of $10^{\circ} \mathrm{C}$ per min and were allowed to cool in furnace. $\mathrm{CH}_{3} \mathrm{NH}_{3} \mathrm{PbI}_{3}$ was deposited by a modified two-step solution processing method. Lead iodide was dissolved in dimethylformamide (DMF) to obtain a $1 \mathrm{M}$ solution. MAI was dissolved in isopropanol at $7 \mathrm{mg} / \mathrm{mL}$. Lead iodide solution was spin-coated on $\mathrm{TiO}_{2}$ coated slides at $3000 \mathrm{rpm}$ for $20 \mathrm{~s}$. Lead iodide coated slides were annealed for $3 \mathrm{~min}$ at $40^{\circ} \mathrm{C}$ and then at $100^{\circ} \mathrm{C}$ for $5 \mathrm{~min}$. They were removed from oven and then mounted on spin coater and MAI was coated at rpm of 3000 for $20 \mathrm{~s}$. Slides were again annealed for $3 \mathrm{~min}$ at $40^{\circ} \mathrm{C}$ and $5 \mathrm{~min}$ at $100^{\circ} \mathrm{C}$ in laboratory oven. Au was thermally evaporated by a mask to define an active area for device of $0.11 \mathrm{~cm}^{2}$.

2.3. Characterization. Microstructure and film morphologies were investigated using scanning electron microscope (JEOL JSM6490A) and atomic force microscope JEOL SPM 5200. Xray diffraction (XRD) studies were done on STOE Stadi MP in $\theta-2 \theta$ mode using $\mathrm{Cu} \mathrm{K} \alpha$ source under tube acceleration voltage of $40 \mathrm{KV}$ and tube current of $20 \mathrm{~mA}$. Measurements were recorded with a step size of $0.04^{\circ}$ and dwell time of $3 \mathrm{~s}$ for each step. ECOPIA HMS-5000 system was used for Hall effect measurements employing Van der Pauw principle. Contacts were made with silver paste on the samples and gold coated spring loaded contacts were used for measurements. Nanovea PS 50 optical profilometer was used to determine the film thicknesses employing Mountains 2D software suite. Cyclic Voltammetry (CV) and impedance spectroscopy were performed using Bilogic EC Lab work station. For CV measurements, platinum counter electrode was used with saturated calomel as reference electrode while the test sample made the working electrode. EC Lab V10.40 software was used for simulation of impedance data. $J-V$ parameters were obtained on Keithley 2400 source meter. Newport 67005 solar simulator with AM $1.5 \mathrm{G}$ filter was used at an irradiance intensity of $100 \mathrm{~mW} / \mathrm{cm}^{2}$. Voltage step was $10 \mathrm{mV}$ with a step time of $40 \mathrm{~ms}$.

\section{Results and Discussion}

As-synthesized GO was investigated for quality of exfoliation. XRD profile in Figure S1 in Supplementary Material available online at http://dx.doi.org/10.1155/2016/8947597 shows peak shifts from $2 \theta$ value of $26.47^{\circ}$ for graphite to $11.8^{\circ}$ for graphene indicating increase in interplaner spacing $d$ from $3.37 \AA$ of graphite to $7.5 \AA$ of graphene due to imbedding of oxygen atoms in graphite lattice [41]. Minor peak broadening at $11.8^{\circ}$ reflects good retention of graphite honey comb lattice in exfoliated sheets [42]. Scanning Electron Microscopy (SEM) study revealed exfoliation of graphite into single and multilayer sheets with lateral dimensions in tens of 


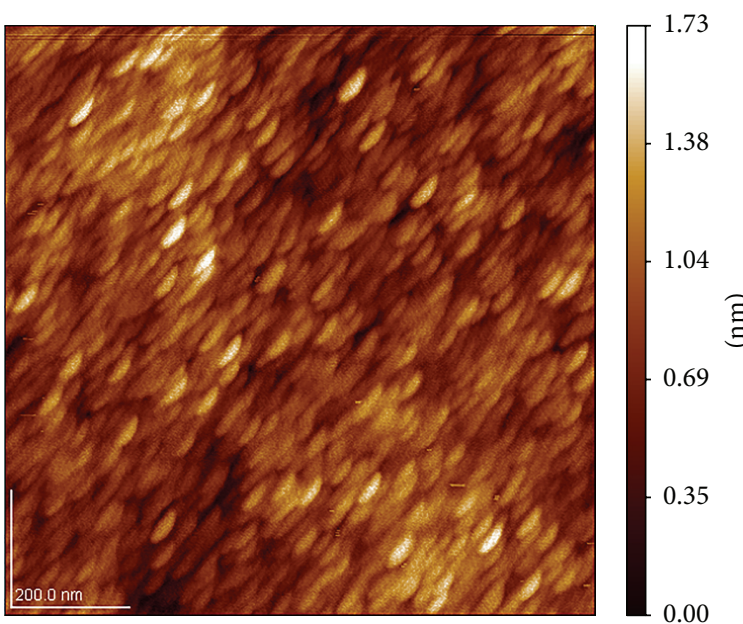

(a)

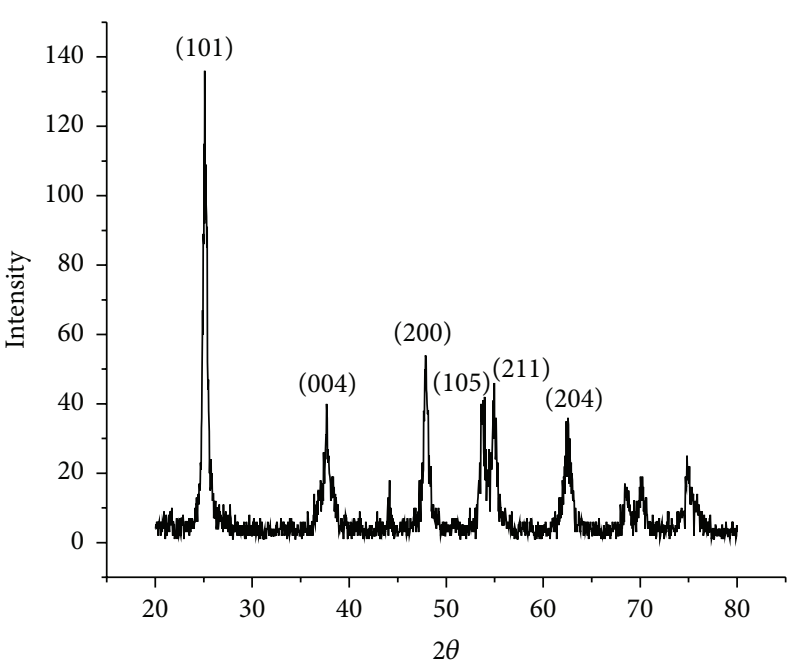

(b)

FIgURE 1: (a) AFM micrograph and (b) XRD pattern of $\mathrm{TiO}_{2}$ film.

micrometers. Taping mode atomic force microscopy (AFM) images (Figure S2) provided evidence for the quality of exfoliation. Dispersions of GO on silicon wafer were studied to avoid any distortion induced by plain glass slide in height profile along $z$-axis. Average roughness in the range of $0.3 \mathrm{~nm}$ and step height of $0.4-1 \mathrm{~nm}$ in the $z$ direction on a flat silicon wafer demonstrates that single sheets of GO have been achieved during the exfoliation process.

Anatase titania nanoparticles were synthesized via sol gel route [43]. The sol was spin-coated on glass slides and studied under SEM and AFM. Uniform particle size distribution was achieved giving compact pin hole free blocking layers. Average particle size was estimated at $20 \mathrm{~nm}$ with a mean square roughness of $0.182 \mathrm{~nm}$ (Figure S3). Film thickness was determined at about $200 \mathrm{~nm}$ (Figure S5) XRD profile in Figure 1 of as-pristine titania confirmed anatase phase with sharp peaks attributed to (101), (004), (200), (105), (211), and (204) planes as outlined in JCPDS 21-1272. Obtained pattern confirms highly crystalline nature of the nanoparticles and the absence of rutile phase [44]. Diffraction patterns were also recorded for $\mathrm{TiO}_{2}$-GO composites with different weight fractions but no additional peak could be observed by addition of GO. By very small quantity of GO in the composite and the fact that diffraction peak for $\mathrm{GO}$ is at $25.0^{\circ}$, it may be masked by strong diffraction for anatase phase at the same $2 \theta$.

Synthesis of titania GO composite was tried by mixing $\mathrm{GO}$ in titania sol and aging it for $24 \mathrm{hr}$ and ultrasonication for $30 \mathrm{~min}$ before spin coating. The results thus achieved were less than perfect, the sol would form gel during the aging process, and when it did age the film formation was nonuniform. Extensive studies under SEM and AFM revealed that the GO in the composite was not covered by the titania nanoparticles but would appear as an agglomerate on the film (Figure S4). Electrical characterization by four-probe Van der Pauw method did not register any improvements in film parameters. We devised a new method whereby to incorporate GO in required weight fraction at the start of the sol gel reaction
TABLE 1: Resistivity values of $\mathrm{TiO}_{2}-\mathrm{GO}$ composites.

\begin{tabular}{lc}
\hline Sample & Resistivity $(\Omega \cdot \mathrm{m})$ \\
\hline 0 wt\% GO in $\mathrm{TiO}_{2}$ & $3.59 \times 10^{5}$ \\
$0.1 \mathrm{wt} \% \mathrm{GO}$ in $\mathrm{TiO}_{2}$ & $2.76 \times 10^{5}$ \\
$0.2 \mathrm{wt} \% \mathrm{GO}$ in $\mathrm{TiO}_{2}$ & $2.04 \times 10^{5}$ \\
$0.3 \mathrm{wt} \% \mathrm{GO}$ in $\mathrm{TiO}_{2}$ & $7.87 \times 10^{4}$ \\
$0.4 \mathrm{wt} \% \mathrm{GO}$ in $\mathrm{TiO}_{2}$ & $7.33 \times 10^{4}$ \\
$0.5 \mathrm{wt} \% \mathrm{GO}$ in $\mathrm{TiO}_{2}$ & $3.62 \times 10^{4}$ \\
\hline
\end{tabular}

as against dispersing GO in the already prepared slurry. This afforded the possibility of incorporation of GO in the sol as a constituent and offers good linking between thin GO films and the particle matrix. SEM micrograph in Figure 2 confirms that the films obtained from the sol prepared by this method were pin hole free and homogeneous and with uniform particle size distribution. GO appeared completely imbedded in the particle matrix with even nanoparticle coverage on the sheets.

Complete dispersion of $\mathrm{GO}$ in $\mathrm{TiO}_{2}$ has resulted in improvement in resistivity over pristine $\mathrm{TiO}_{2}$ films. These improvements are attributed to superior charge carrier properties of GO, reducing interfacial resistance between $\mathrm{TiO}_{2}$ nanoparticles. GO provides a two-dimensional conductive framework for anchoring of nanoparticles. Though higher GO concentrations resulted in greater reduction of resistivity, the films formed were of poor quality with delamination at GO titania interface resulting in shortening of the devices. Best quality films were obtained with $0.4 \mathrm{wt} \%$ of $\mathrm{GO}$ in $\mathrm{TiO}_{2}$ and were subsequently used for further studies. This concentration corresponds to the reported optimum for obtaining best GO sheet surface coverage with $\mathrm{TiO}_{2}$ nanoparticles [36]. Resistivity values are tabulated in Table 1 and are in good agreement with reported values [45].

Efforts to reproduce the reported procedure [17] for synthesis of $\mathrm{CH}_{3} \mathrm{NH}_{3} \mathrm{PbI}_{3}$ under ambient conditions in our lab could not result in uniform films (Figure S8). Modifications 

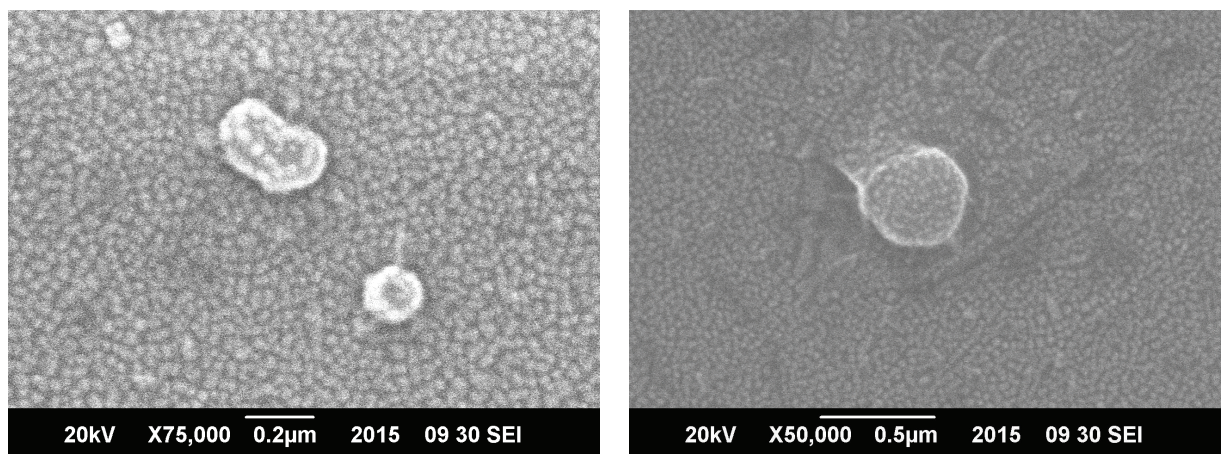

FIgURE 2: SEM micrographs of $\mathrm{TiO}_{2}-\mathrm{GO}$ composite prepared by in situ incorporation of $\mathrm{GO}$ in sol gel reaction.

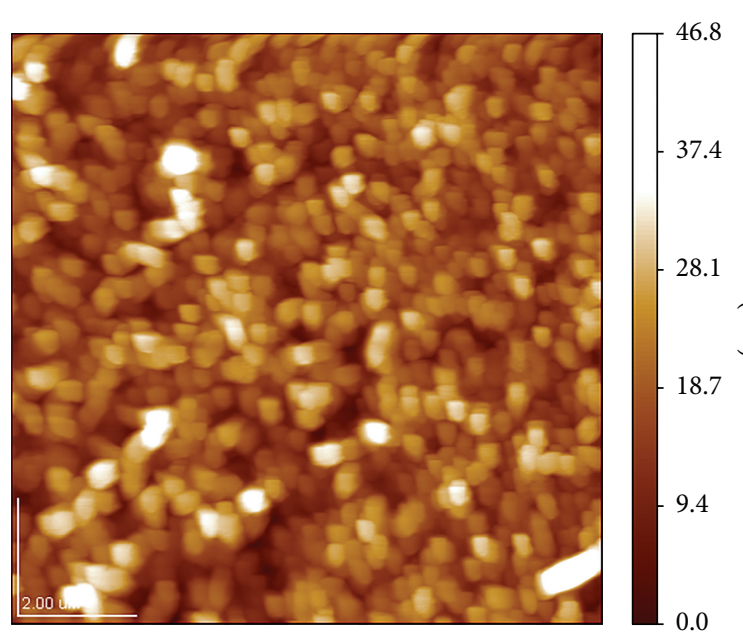

(a)

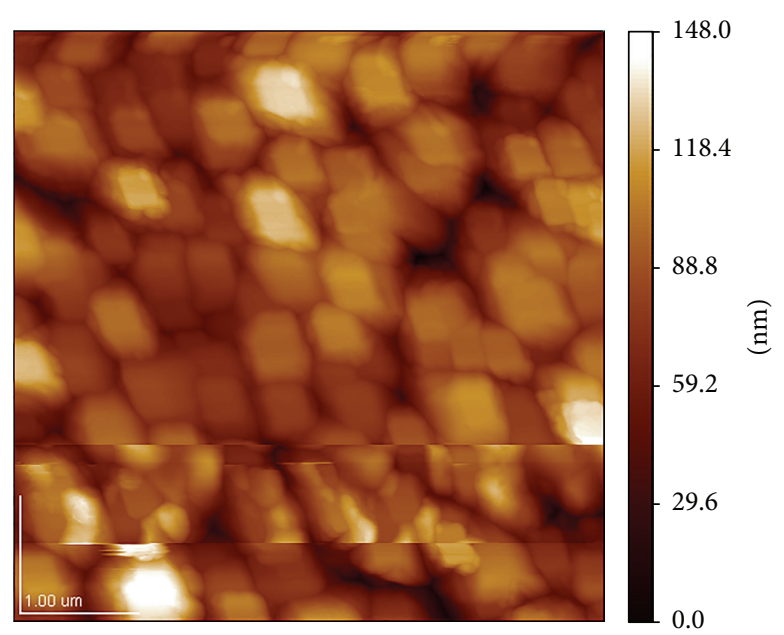

(b)

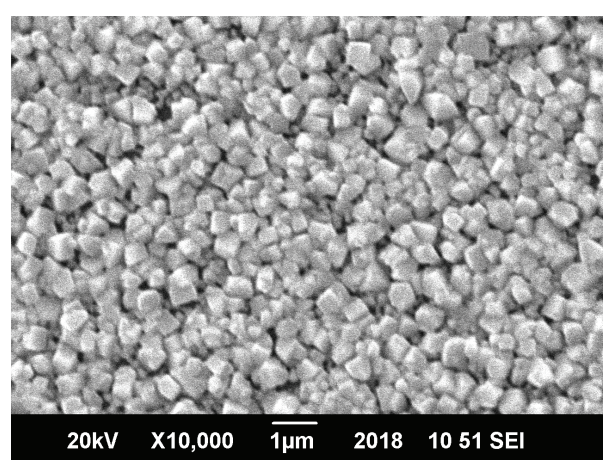

(c)

Figure 3: (a) AFM micrographs of $\mathrm{PbI}_{2}$ film, (b) needle like morphology transformed to cuboids by wetting with $\mathrm{CH}_{3} \mathrm{NH}_{3} \mathrm{I}$ as is evident from AFM image, and (c) low magnification large area SEM micrograph. Scale bars in (a) and (b) represent $2 \mu \mathrm{m}$.

were tried and the one being reported resulted in complete surface coverage of the devices with uniform pin hole free morphology. Lead iodide at $1 \mathrm{M}$ solution in DMF was heated to $70^{\circ} \mathrm{C}$ and was spin-coated on a substrate heated to $50^{\circ} \mathrm{C}$ under ambient conditions at $3000 \mathrm{rpm}$ for $20 \mathrm{~s}$ and subsequently annealed at $40^{\circ} \mathrm{C}$ for $3 \mathrm{~min}$ and $100^{\circ} \mathrm{C}$ for $5 \mathrm{~min}$. The lead iodide coated films were then mounted on a spin coater and $20 \mu \mathrm{L}$ of isopropanol was added while the sample was spinning followed by drop-wise addition of MAI solution in isopropanol. During this step the sample was spun at
$3000 \mathrm{rpm}$ for $20 \mathrm{~s}$. The films acquired a light brown color. Subsequent to this step MAI solution in isopropanol was added on the slide and was given a soaking time of $20 \mathrm{~s}$ and then spun at $3000 \mathrm{rpm}$ for $20 \mathrm{~s}$ again. While the sample rotated it was dried with hot air blown on it by a hair dryer. This resulted in rapid crystallization and the film acquired a blackish texture and was further annealed in oven at $40^{\circ} \mathrm{C}$ for $3 \mathrm{~min}$ followed by $100^{\circ} \mathrm{C}$ for $5 \mathrm{~min}$.

Study of lead iodide films (Figure 3(a) and Figure S6) reveled a needle like morphology which was transformed 


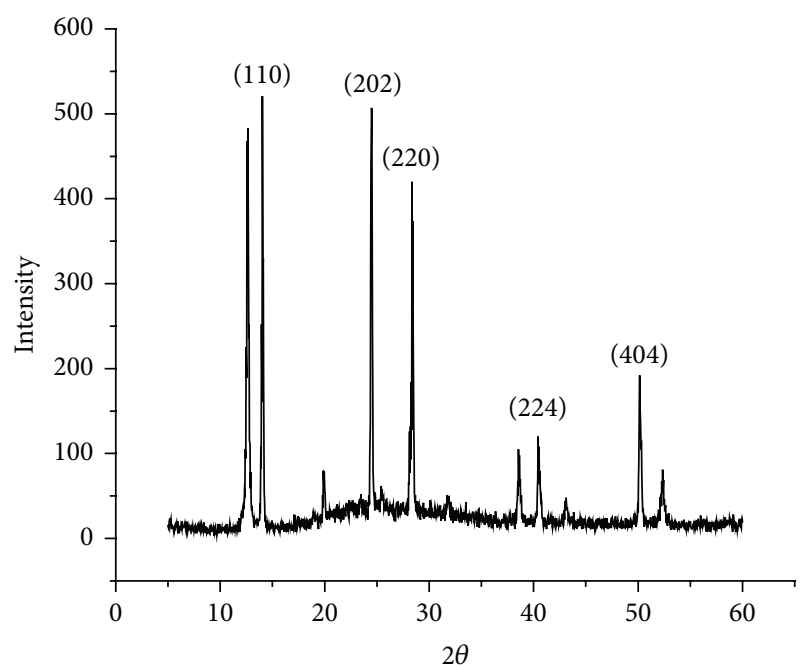

FIGURE 4: XRD profile of $\mathrm{CH}_{3} \mathrm{NH}_{3} \mathrm{PbI}_{3}$.

to $\mathrm{CH}_{3} \mathrm{NH}_{3} \mathrm{PbI}_{3}$ upon wetting with MAI solution in isopropanol. The grains grew and the morphology evolved from a needle like structure to a cuboid morphology with grains ranging in submicron size in lateral dimensions. Large area low magnification scan in Figures 3(b) and 3(c) reveals the efficiency of the developed synthesis technique. AFM micrographs in Figure S7 exhibited a surface roughness of $14.5 \mathrm{~nm}$ with average grain of the size in microns, thus showing that the grains grow more rapidly in lateral dimension than vertical. Large grain size and large area uniform coverage correspond well with reported observations that humidity has a beneficial effect in grain growth allowing grain boundary creep resulting in larger and uniform coverage [46, 47]. Smaller overall grain boundary surface area avoids energetic disorders allowing reliable photovoltaic performance from ambient air synthesized devices.

Strong diffraction intensities at 14.0, 24.3, 28.4, 40.5, 43.0, and $50.3^{\circ}$ in Figure 4 correspond to reflections from (110), (202), (220), (224), (314), and (404) planes confirming tetragonal phase of absorber [37, 48-50]. Intensities of the signals are an indication of crystallinity of film. In addition to these peaks, peaks for lead iodide can also be observed in the pattern suggestive of residual lead iodide in the films.

This residual $\mathrm{PbI}_{2}$ is not detrimental to the photovoltaic performance of the devices as residual lead iodide at the boundaries and interfaces has been reported to improve the carrier properties of the films by improved carrier life times and reducing recombination by electrons from titania and holes from $\mathrm{CH}_{3} \mathrm{NH}_{3} \mathrm{PbI}_{3}$.

Optimum titania GO composite was used to prepare complete devices. A $200 \mathrm{~nm}$ thick blocking layer was deposited by spin coating. Absorber layer at a thickness of about $400 \mathrm{~nm}$ was deposited followed by thermal evaporation of $100 \mathrm{~nm} \mathrm{Au}$ electrode. Cross section FE SEM image at Figure 5(c) demonstrates the device architecture. Current voltage curves for device based on $\mathrm{TiO}_{2}$ only and $\mathrm{TiO}_{2}-\mathrm{GO}$ blocking layer are presented in Figure 5(a) along with tabulated performance parameters. Performance enhancement for $\mathrm{TiO}_{2}-\mathrm{GO}$ based devices can be attributed to energetically favorable energy scheme (Figure 5(b)) where GO provides an intermediate step between $\mathrm{CH}_{3} \mathrm{NH}_{3} \mathrm{PbI}_{3}$ and $\mathrm{TiO}_{2}$. Higher mobility of $\mathrm{GO}$ also provides improved conductivity over $\mathrm{TiO}_{2}$ only devices. Higher FF for these devices over $\mathrm{TiO}_{2}$ only devices is an indication of reduced series resistance.

Quantifiable evidence for the decrease in series resistance and other device parameters was provided by impedance spectroscopy. Impedance spectroscopy (IS) is a very versatile technique and has been extensively employed for analysis of photovoltaic (PV) device including DSSC and polymeric solar cells [51-55]. It affords the opportunity to model and evaluate performance of solar cells in terms of equivalent circuit offering an opportunity to improve the performance by addressing target components in terms of equivalent resistance values. IS was obtained for the prepared devices from a frequency range of $1 \mathrm{MHz}$ to $500 \mathrm{mHz}$ at bias voltage between $100 \mathrm{mV}$ and $800 \mathrm{mV}$ and oscillation potential amplitude of $20 \mathrm{mV}$. Simulated circuit element values are presented in Figures 6 and 7 while Nyquist plots are depicted in Figure 8. They reflect a typical feature characteristic for solar cells commonly described using a transmission line model [56].

Two RC elements with a series resistance $R_{\mathrm{s}}$ have been used as equivalent circuit to model the experimental results. Resistances associated with ITO and circuit wires are demonstrated by $R_{\mathrm{s}}$ and an additional RC component models the contribution due to shunt resistance and the capacitance of the active layer. Constant phase elements are used instead of ideal capacitors for better data fit. They are part of an equivalent circuit depicted in Figure 6.

Nyquist plots present two characteristic arcs, one low frequency and an intermediate frequency arc. While the intermediate frequency arc is associated with recombination in the active layer, the source of low frequency arc is debated. Some associate it with ferroelectric domain wall controlled charge accumulation [57] while others have attributed it to the trap state distribution in $\mathrm{CH}_{3} \mathrm{NH}_{3} \mathrm{PbI}_{3}$ [51]. Another thought is for the difference in electron affinities at the perovskite interfaces being the source of this feature [58]. Some have even postulated that it has no bearing on the device physics and have left it out of the curve fitting process [25]. In DSSCs, this low frequency feature was associated with ion migration in liquid electrolyte; evidence of ionic mobility in $\mathrm{CH}_{3} \mathrm{NH}_{3} \mathrm{PbI}_{3}$ has been presented $[59,60]$ and can be the source of this low frequency feature in $\mathrm{CH}_{3} \mathrm{NH}_{3} \mathrm{PbI}_{3}$ based devices.

Graphical trend for the values of $R_{\mathrm{s}}, R_{\mathrm{sc}}$, and $R_{\text {rec }}$ is depicted in Figure 6. $R_{\mathrm{s}}$ and $R_{\mathrm{sc}}$ contribute to the total series resistance [58] and the addition of $\mathrm{GO}$ in $\mathrm{TiO}_{2}$ matrix results in lowering of the total series resistance. Since IS measurements are not sensitive to the photocurrent, only FF and $V_{o c}$ are the parameters that can be attributed to the calculated values [56]. The decrease in series resistance is the cause of increased FF for devices with titania GO composites.

Recombination rate in the active layer can be demonstrated by the variation of the recombination resistance with bias voltage. $R_{\text {rec }}$ is calculated from the intermediate frequency feature of the Nyquist plot [58]. The higher the recombination resistance, the lower the recombination rate 


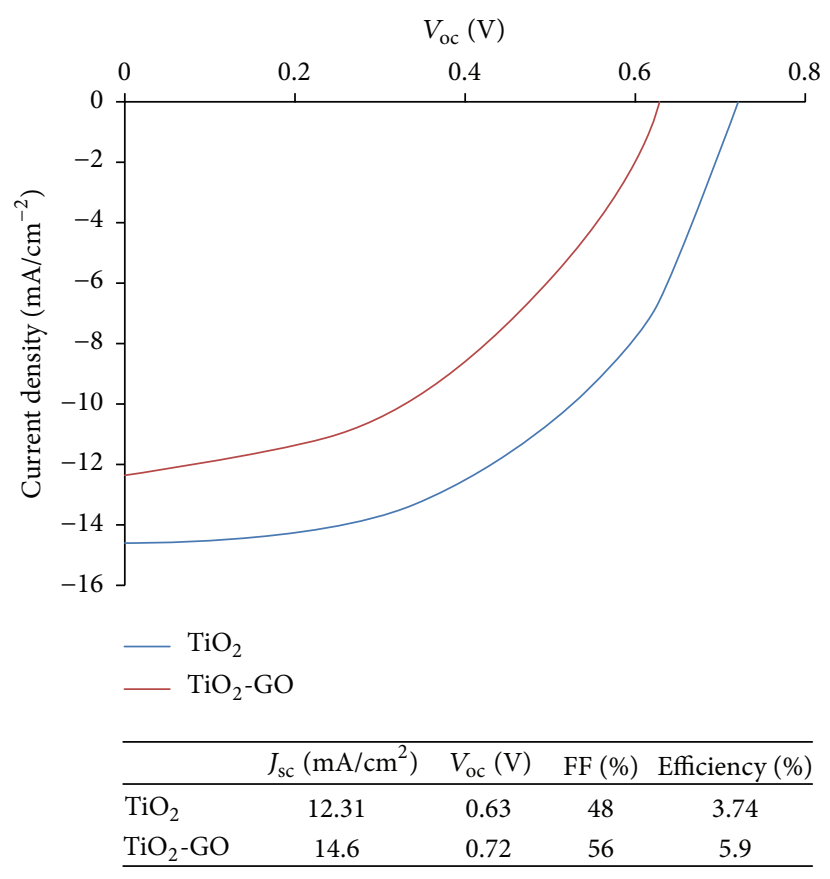

(a)

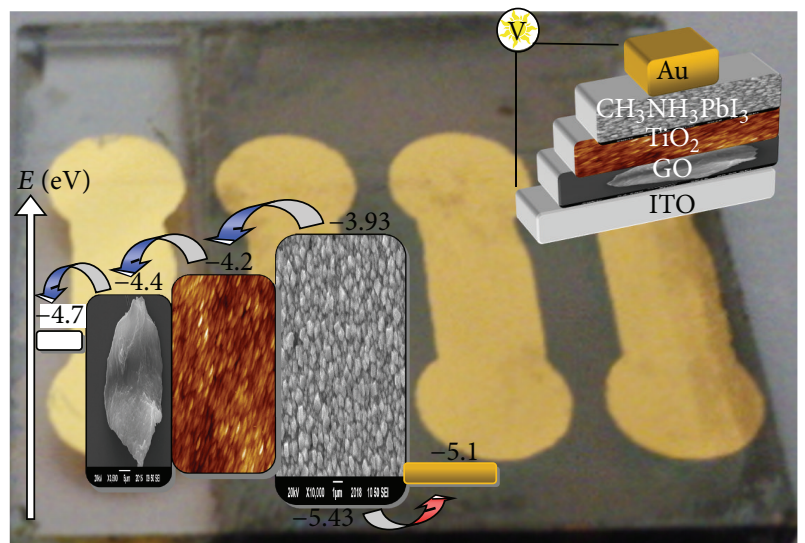

(b)

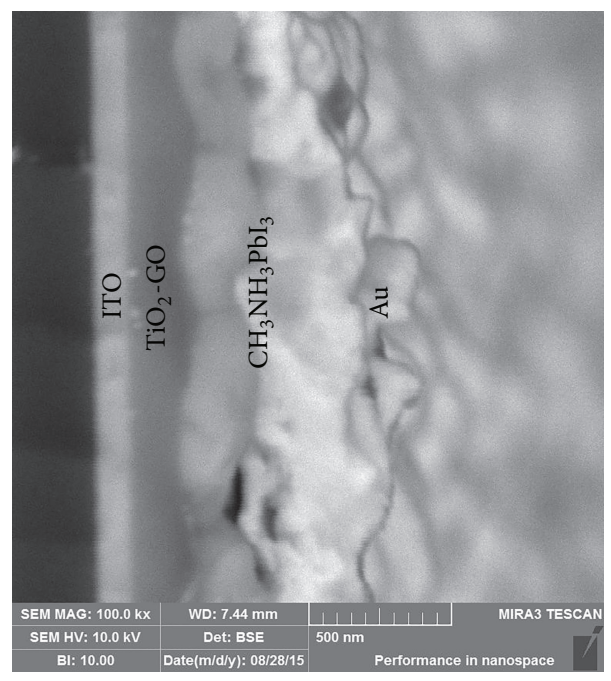

(c)

Figure 5: (a) $J-V$ curves for $\mathrm{TiO}_{2}$ and $\mathrm{TiO}_{2}$-GO based solar cells. (b) Schematic of complete device along with energy levels overlaid on completed device. (c) SEM image of cross section profile of complete device.

and vice versa. Recombination rates dictate the value of $V_{\text {oc }}$; thus lower recombination rate translates into higher $V_{\mathrm{oc}}$. Slope of $R_{\text {rec }}$ presents an idea of the FF of the devices; lower slope represents a higher FF. With the addition of GO in $\mathrm{TiO}_{2}$, the value of $R_{\text {rec }}$ is increased for the composite validating the observation of higher $V_{\text {oc }}$ for the devices based on nanocomposite electron selective contact.

Capacitance values associated with intermediate frequency arc are associated with charge accumulation or separation with the absorber interfaces. The values do not change with the changing potential and remain almost constant for the entire potential range at the order of $10^{-9} \mathrm{~F} \mathrm{~cm}^{-2}$.
Variation of bias voltage results in increasing carrier densities and the invariance of capacitance with this increasing density is another manifestation of the long diffusion lengths for $\mathrm{CH}_{3} \mathrm{NH}_{3} \mathrm{PbI}_{3}$ absorbers [61].

In order to evaluate the performance of devices at elevated temperatures, impedance measurements were repeated by heating the samples at $40^{\circ} \mathrm{C}$ and at $60^{\circ} \mathrm{C}$. A decreasing trend of $R_{\mathrm{s}}$ and $R_{\mathrm{sc}}$ with an increase in $R_{\mathrm{rec}}$ with the increase of temperature to $40^{\circ} \mathrm{C}$ can be inferred as an evidence of the increase in the photovoltaic performance of the devices under study. Increasing the temperature to $60^{\circ} \mathrm{C}$ results in sharp increase in $R_{\mathrm{s}}$ and $R_{\mathrm{sc}}$ along with decay in the value of $R_{\mathrm{rec}}$. 

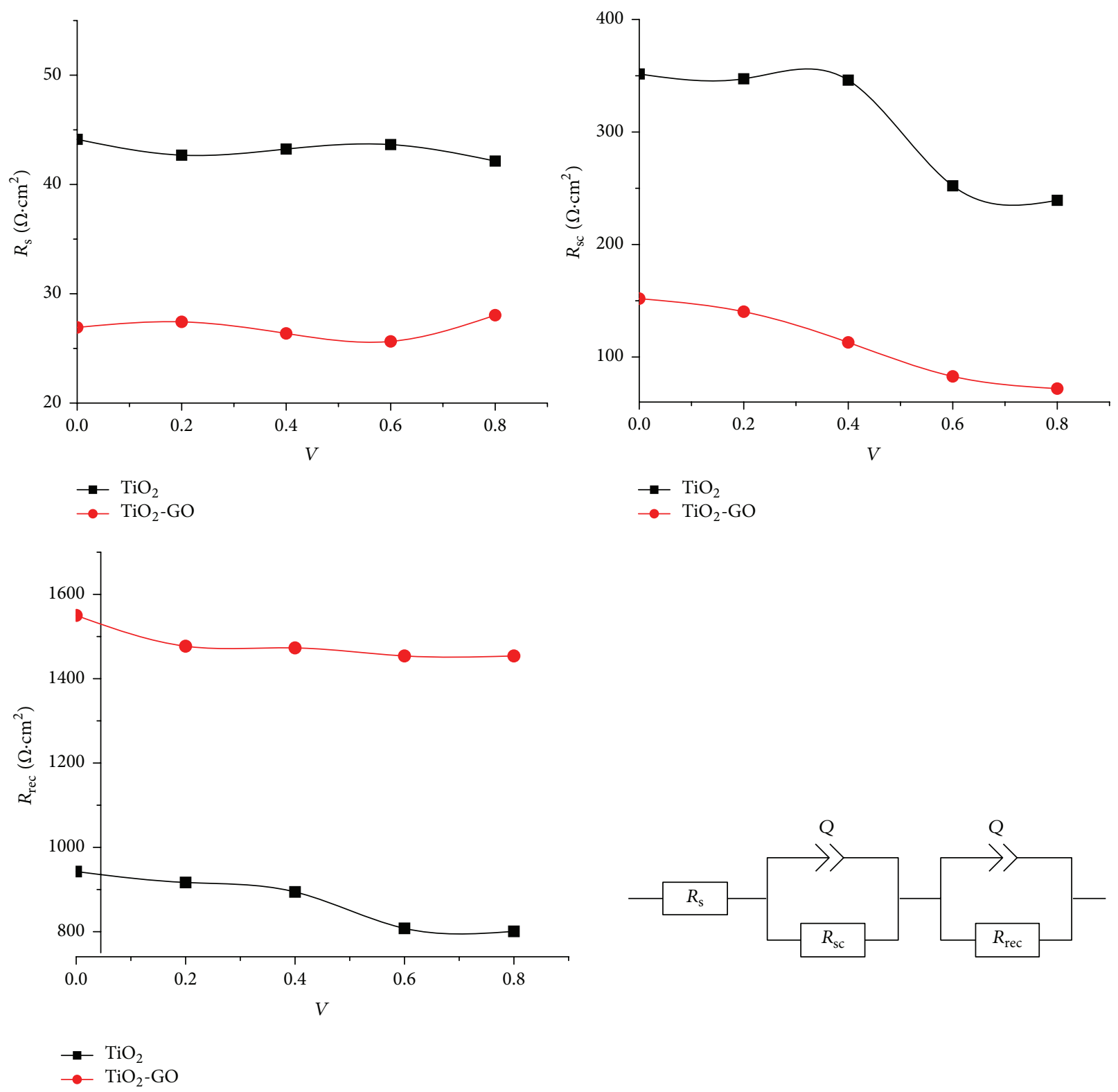

FIgure 6: $R_{\mathrm{s}}, R_{\mathrm{sc}}$, and $R_{\text {rec }}$ plots for $\mathrm{TiO}_{2}$ and $\mathrm{TiO}_{2}-\mathrm{GO}$ based devices, with equivalent circuit.

This trend demonstrates a decreasing performance of devices at $60^{\circ} \mathrm{C}$. This decrease in performance can be associated with phase change of $\mathrm{CH}_{3} \mathrm{NH}_{3} \mathrm{PbI}_{3}$ from tetragonal phase to cubic phase at $55^{\circ} \mathrm{C}$ [62]. Additionally, the difference in the coefficient of thermal expansion mismatch can have a deleterious effect with increasing temperatures [63]; this increased mismatch increases the defect states which associated with higher recombination rates at the interface effects the density of states. Increase of recombination rate is manifested by a decrease of $R_{\text {rec }}$ values in impedance plot and the interfacial mismatch and increased defect densities resulting in increase of series resistance by increasing $R_{\mathrm{sc}}$.

Devices were stored under ambient air conditions for $1000 \mathrm{hr}$ without encapsulation and tested again; devices retained $73 \%$ of original efficiency. Enhanced stability can be explained by the band gap modification of $\mathrm{TiO}_{2}$ with incorporation of GO causing a shift to the visible spectrum [64]. Titania is a wide band gap semiconductor and affords efficient electron uptake from active layer with high mobility and solution processability under ambient conditions. A band gap of 3.2, photoexcitation, is achieved in UV range and is typically employed as photocatalyst for oxidation of organic matter [65].

Degradation mechanism for $\mathrm{CH}_{3} \mathrm{NH}_{3} \mathrm{PbI}_{3}$ at the interface of titania is postulated as [66]

$$
2 \mathrm{I}^{-} \longleftrightarrow \mathrm{I} 2+2 \mathrm{e}^{-}
$$

[at the interface between $\mathrm{TiO}_{2}$ and $\mathrm{CH}_{3} \mathrm{NH}_{3} \mathrm{PbI}_{3}$ ]

$$
3 \mathrm{CH}_{3} \mathrm{NH}_{3}^{+} \longleftrightarrow 3 \mathrm{CH}_{3} \mathrm{NH}_{2} \uparrow+3 \mathrm{H}^{+}
$$

$\mathrm{I}^{-}+\mathrm{I}_{2}+3 \mathrm{H}^{+}+2 \mathrm{e}^{-} \longleftrightarrow 3 \mathrm{HI} \uparrow$ 

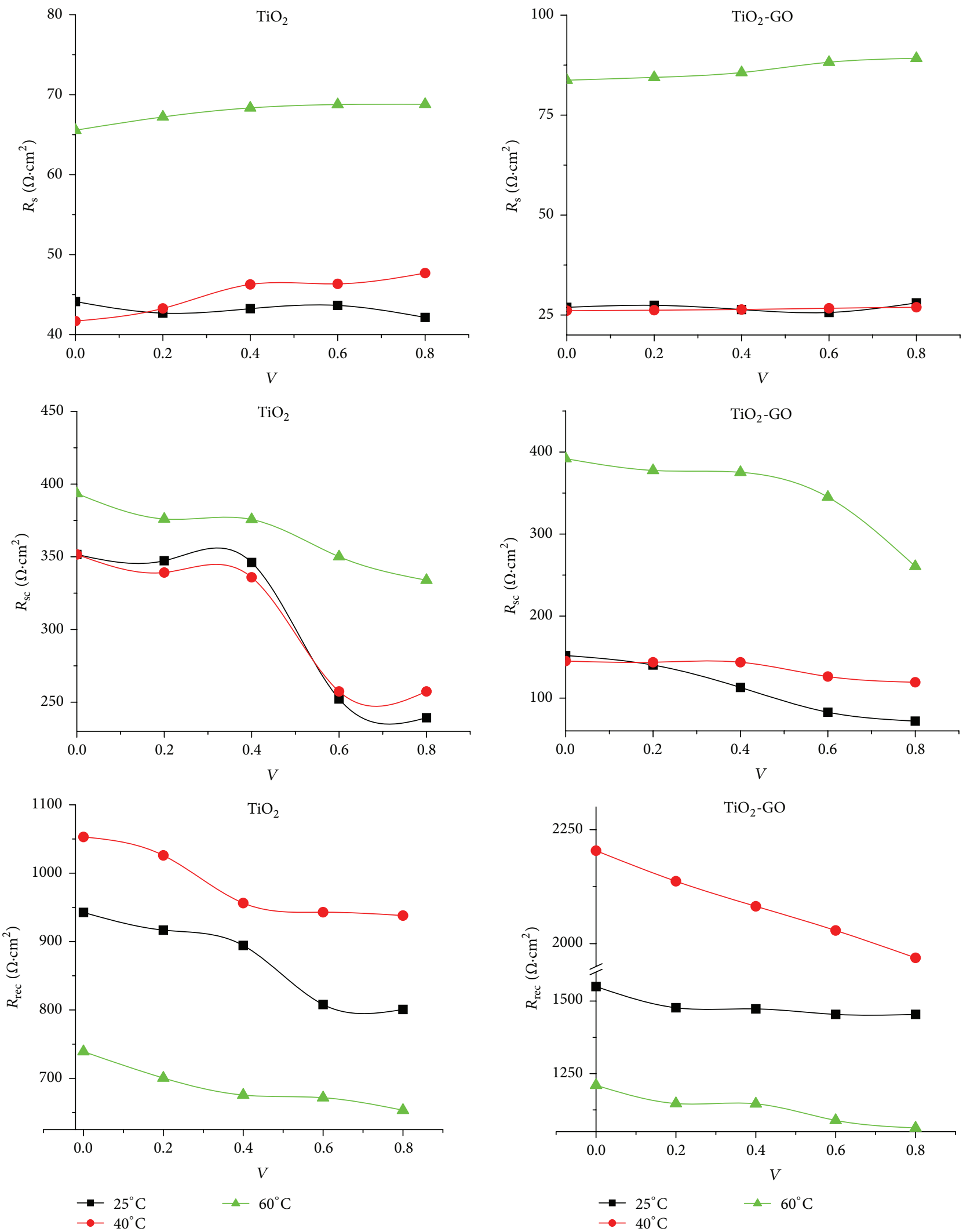

FIgURE 7: $R_{\mathrm{s}}, R_{\mathrm{sc}}$, and $R_{\text {rec }}$ plots for $\mathrm{TiO}_{2}$ and $\mathrm{TiO}_{2}$-GO based devices obtained at different temperatures. Legend along each plot indicates the test conditions. 


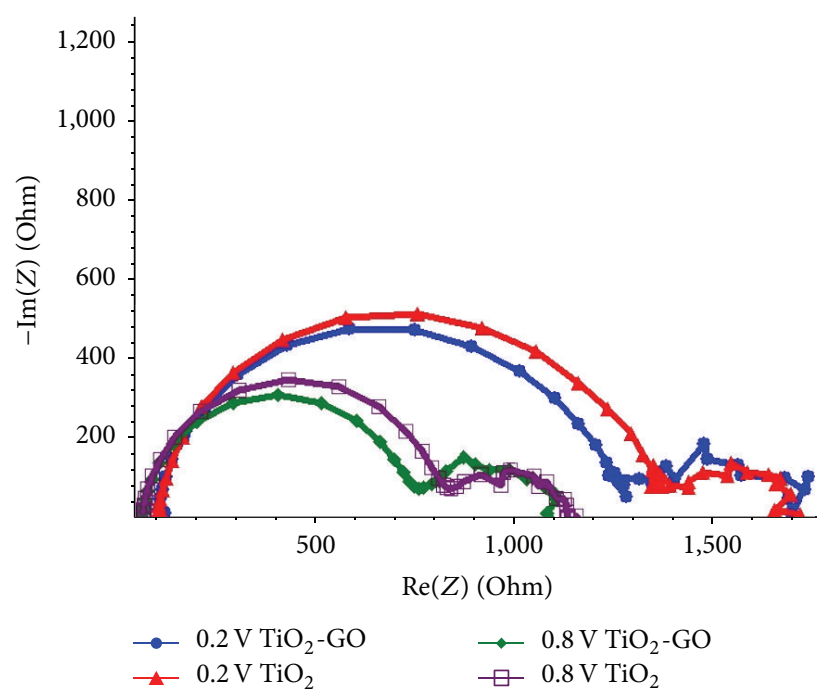

(a)

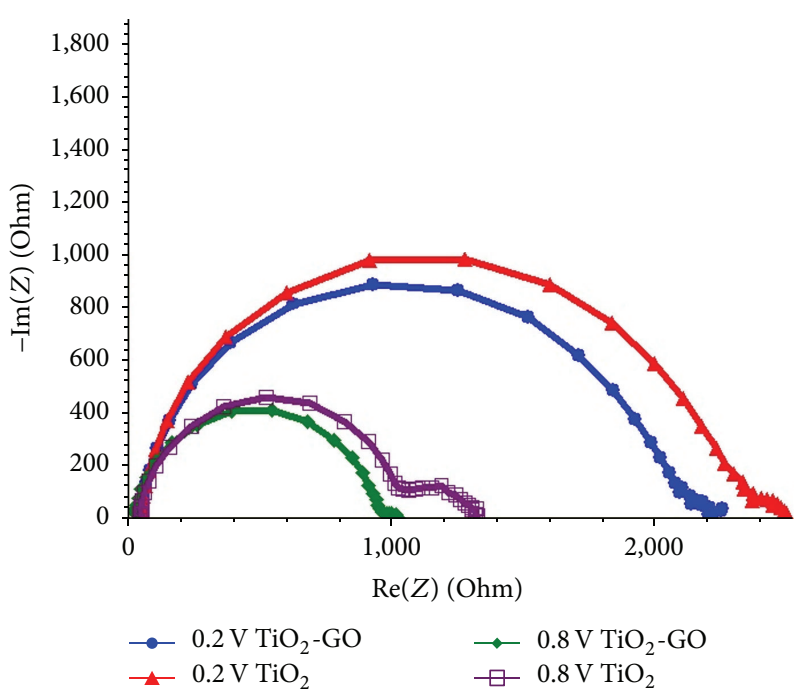

(b)

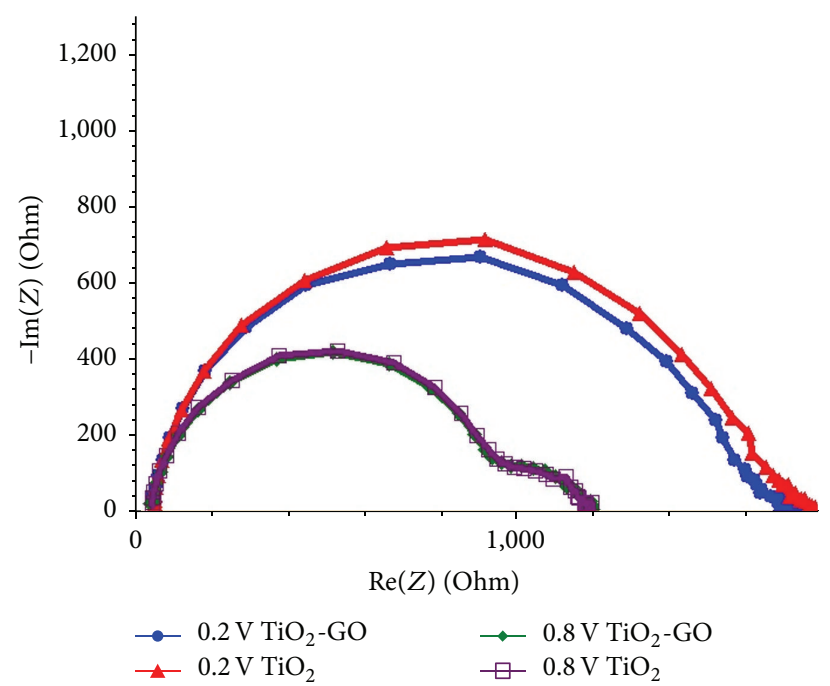

(c)

Figure 8: Nyquist plots for $\mathrm{TiO}_{2}$ and $\mathrm{TiO}_{2}$-GO based devices; (a), (b), and (c) are plots at 25, 40, and $60^{\circ} \mathrm{C}$, respectively.

Titania acts as an oxidizing agent for $\mathrm{I}^{-}$, at the interface, resulting in the loss of perovskite crystal structure by forming lead iodide and $\mathrm{CH}_{3} \mathrm{NH}_{2}$, which is rapidly lost due to its low bp of $17^{\circ} \mathrm{C}$. Systematic studies have addressed the issue of UV sensitivity by using interfacial layer of $\mathrm{Sb}_{2} \mathrm{~S}_{3}$, UV filters, employing zirconia or alumina scaffolds and aluminosilicate shells around titania particles [67-69]. UV sensitivity of this interface can be addressed if the absorption edge of titania can be shifted to visible range. It has been demonstrated that the absorption edge of titania can be shifted to visible range due to electronic coupling between $p$ states of the imbedded graphene and the titania conduction band [70].

Band gap of titania GO composite in our work was investigated using CV (Figure S9) and HOMO/LUMO levels were calculated by the following equations:

$$
\begin{aligned}
& E_{\mathrm{HOMO}}=-E_{\text {ox }}{ }^{\text {onset }}-4.8(\mathrm{eV}) \\
& E_{\mathrm{LUMO}}=-E_{\text {red }}{ }^{\text {onset }}-4.8(\mathrm{eV}) .
\end{aligned}
$$

TABLE 2: Band gaps for different concentrations of $\mathrm{TiO}_{2}-\mathrm{GO}$ composite.

\begin{tabular}{lc}
\hline Composition & Band gap $(\mathrm{eV})$ \\
\hline Titania & 3.18 \\
0.1 wt $\%$ GO & 3.11 \\
0.2 wt $\%$ GO & 3.05 \\
0.3 wt $\%$ GO & 2.99 \\
0.4 wt $\%$ GO & 2.95 \\
\hline
\end{tabular}

Band gaps obtained with changing GO concentrations are tabulated (Table 2). Shift in band gap can be a possible source for improved efficiency of the devices addressing the degradation mechanism at titania $\mathrm{CH}_{3} \mathrm{NH}_{3} \mathrm{PbI}_{3}$ interface.

Planer geometry $\mathrm{CH}_{3} \mathrm{NH}_{3} \mathrm{PbI}_{3}$ cells have been associated with hysteresis in $J-V$ curves. Low hysteresis observed in our devices may be because of the low efficiencies as compared to 
the extremely efficient cells with record efficiencies. Another thought can be because of the interface engineering effects at the electron selective contact and $\mathrm{CH}_{3} \mathrm{NH}_{3} \mathrm{PbI}_{3}$ and $\mathrm{TiO}_{2}$ interface with TCO because of the addition of GO that can be attributed to this reduction in hysteresis [46, 71, 72]. A potential barrier to electron transfer exists at $\mathrm{CH}_{3} \mathrm{NH}_{3} \mathrm{PbI}_{3}$ $\mathrm{TiO}_{2}$ interface as demonstrated by Xing et al. $[73,74]$ and any improvement in the charge collection efficiency at this interface can result in improved photovoltaic performance and reduced hysteresis. Jena and coworkers have presented conclusive evidence that hysteresis observed in these devices not only is because of the bulk properties of the $\mathrm{CH}_{3} \mathrm{NH}_{3} \mathrm{PbI}_{3}$ like ion migration and ferroelectric behavior but also is strongly affected by the interfaces associated with the bulk of the material [75]. A missing interface at $\mathrm{CH}_{3} \mathrm{NH}_{3} \mathrm{PbI}_{3} \mathrm{HTL}$ junction has the advantage of reducing hysteresis combined with modified electron selective contact at the other interface. Any modification of $\mathrm{TiO}_{2}$ which reduces the trap states effects the buildup of capacitance at the interfaces by allowing rapid charge collection. Also band alignment of $\mathrm{TiO}_{2}$ at the TCO and $\mathrm{CH}_{3} \mathrm{NH}_{3} \mathrm{PbI}_{3}$ end can affect the band bending during forward and reverse scan directions. Passivation of the trap states, enhanced electron mobility, and suitable band alignments are all the benefits associated with $\mathrm{TiO}_{2}-\mathrm{GO}$ nanocomposite, which can be a possible reason for low $J-V$ hysteresis in studied devices.

\section{Conclusions}

We demonstrated a $\mathrm{CH}_{3} \mathrm{NH}_{3} \mathrm{PbI}_{3}$ solar cell using $\mathrm{TiO}_{2}$ GO nanocomposite as electron selective contact in a hole transport layer free architecture. Ambient air synthesis route was adopted and PCE of 5.9\% was achieved. Novel technique is introduced to obtain $\mathrm{TiO}_{2}$ - $\mathrm{GO}$ nanocomposite by in situ incorporation of GO during the sol gel reaction. Band gap was engineered for higher stability of the devices. Incorporation of GO had a synergetic effect by passivation of the trap states in $\mathrm{TiO}_{2}$. This along with band gap engineering may be responsible for reduced hysteresis effects. Enhanced stability, reduced hysteresis, and an ambient air synthesis route with hole transport layer free geometry have the potential to reduce cost and enhance commercial viability of this technology.

\section{Competing Interests}

The authors declare that they have no competing interests.

\section{Acknowledgments}

The authors thank staff at National Nanotechnology Research Centre, Institute of Materials Science and Nanotechnology, Bilkent University, Turkey, for help with $J-V$ characterization. This research was funded by Higher Education Commission Pakistan through Grant no. 213-58732-2EG2-014 (50023541).

\section{References}

[1] W. S. Yang, J. H. Noh, N. J. Jeon et al., "High-performance photovoltaic perovskite layers fabricated through intramolecular exchange," Science, vol. 348, no. 6240, pp. 1234-1237, 2015.
[2] S. De Wolf, J. Holovsky, S.-J. Moon et al., "Organometallic halide perovskites: sharp optical absorption edge and its relation to photovoltaic performance," Journal of Physical Chemistry Letters, vol. 5, no. 6, pp. 1035-1039, 2014.

[3] X. Ziang, L. Shifeng, Q. Laixiang et al., "Refractive index and extinction coefficient of $\mathrm{CH}_{3} \mathrm{NH}_{3} \mathrm{PbI}_{3}$ studied by spectroscopic ellipsometry," Optical Materials Express, vol. 5, no. 1, pp. 29-43, 2015.

[4] H.-S. Kim, I. Mora-Sero, V. Gonzalez-Pedro et al., "Mechanism of carrier accumulation in perovskite thin-absorber solar cells," Nature Communications, vol. 4, article 2242, 2013.

[5] S. D. Stranks, G. E. Eperon, G. Grancini et al., "Electron-hole diffusion lengths exceeding 1 micrometer in an organometal trihalide perovskite absorber," Science, vol. 342, no. 6156, pp. 341-344, 2013.

[6] G. Xing, N. Mathews, S. Sun et al., "Long-range balanced electron- and hole-transport lengths in organic-inorganic $\mathrm{CH}_{3} \mathrm{NH}_{3} \mathrm{PbI}_{3}$," Science, vol. 342, no. 6156, pp. 344-347, 2013.

[7] P. V. Kamat, "Quantum dot solar cells. The next big thing in photovoltaics," Journal of Physical Chemistry Letters, vol. 4, no. 6, pp. 908-918, 2013.

[8] A. Kojima, K. Teshima, Y. Shirai, and T. Miyasaka, "Novel photoelectrochemical cell with mesoscopic electrodes sensitized by lead-halide compounds (11)," Meeting Abstract, vol. MA2008-02 27, no. 1, p. 27, 2008.

[9] R. Sheng, A. Ho-Baillie, S. Huang et al., "Methylammonium lead bromide perovskite-based solar cells by vapor-assisted deposition," The Journal of Physical Chemistry C, vol. 119, no. 7, pp. 3545-3549, 2015.

[10] H.-S. Kim, S. H. Im, and N.-G. Park, "Organolead halide perovskite: new horizons in solar cell research," Journal of Physical Chemistry C, vol. 118, no. 11, pp. 5615-5625, 2014.

[11] J. Burschka, A. Dualeh, F. Kessler et al., "Tris(2-(1H -pyrazol-1yl)pyridine)cobalt(III) as p-type dopant for organic semiconductors and its application in highly efficient solid-state dyesensitized solar cells," Journal of the American Chemical Society, vol. 133, no. 45, pp. 18042-18045, 2011.

[12] D. Bi, S.-J. Moon, L. Häggman et al., "Using a two-step deposition technique to prepare perovskite $\left(\mathrm{CH}_{3} \mathrm{NH}_{3} \mathrm{PbI}_{3}\right)$ for thin film solar cells based on $\mathrm{ZrO}_{2}$ and $\mathrm{TiO}_{2}$ mesostructures," RSC Advances, vol. 3, no. 41, pp. 18762-18766, 2013.

[13] D. Bi, L. Yang, G. Boschloo, A. Hagfeldt, and E. M. J. Johansson, "Effect of different hole transport materials on recombination in $\mathrm{CH}_{3} \mathrm{NH}_{3} \mathrm{PbI}_{3}$ perovskite-sensitized mesoscopic solar cells," Journal of Physical Chemistry Letters, vol. 4, no. 9, pp. 1532-1536, 2013.

[14] E. Edri, S. Kirmayer, A. Henning et al., "Why lead methylammonium tri-iodide perovskite-based solar cells require a mesoporous electron transporting scaffold (but not necessarily a hole conductor)," Nano Letters, vol. 14, no. 2, pp. 1000-1004, 2014.

[15] A. Mei, X. Li, L. Liu et al., "A hole-conductor-free, fully printable mesoscopic perovskite solar cell with high stability," Science, vol. 345, no. 6194, pp. 295-298, 2014.

[16] S. Ye, W. Sun, Y. Li et al., "CuSCN-based inverted planar perovskite solar cell with an average PCE of 15.6\%," Nano Letters, vol. 15, no. 6, pp. 3723-3728, 2015.

[17] H.-S. Ko, J.-W. Lee, and N.-G. Park, "15.76\% Efficiency perovskite solar cells prepared under high relative humidity: importance of $\mathrm{PbI}_{2}$ morphology in two-step deposition of $\mathrm{CH}_{3} \mathrm{NH}_{3} \mathrm{PbI}_{3}$," Journal of Materials Chemistry A, vol. 3, no. 16, pp. 8808-8815, 2015. 
[18] J. Borchert, H. Boht, W. Fränzel, R. Csuk, R. Scheer, and P. Pistor, "Structural investigation of co-evaporated methyl ammonium lead halide perovskite films during growth and thermal decomposition using different $\mathrm{PbX}_{2}(\mathrm{X}=\mathrm{I}, \mathrm{Cl})$ precursors," Journal of Materials Chemistry A, vol. 3, no. 39, pp. 19842-19849, 2015.

[19] Q. Ke, M. Zheng, H. Liu, C. Guan, L. Mao, and J. Wang, “3D $\mathrm{TiO}_{2} @ \mathrm{Ni}(\mathrm{OH})_{2}$ core-shell arrays with tunable nanostructure for hybrid supercapacitor application," Scientific Reports, vol. 5, Article ID 13940, 2015.

[20] D. H. Kim, G. S. Han, W. M. Seong et al., "Niobium doping effects on $\mathrm{TiO}_{2}$ mesoscopic electron transport layer-based perovskite solar cells," ChemSusChem, vol. 8, no. 14, pp. 23922398, 2015.

[21] S. K. Pathak, A. Abate, P. Ruckdeschel et al., "Performance and stability enhancement of dye-sensitized and Perovskite solar cells by $\mathrm{Al}$ doping of $\mathrm{TiO}_{2}$," Advanced Functional Materials, vol. 24, no. 38, pp. 6046-6055, 2014.

[22] P. Qin, A. L. Domanski, A. K. Chandiran et al., "Yttriumsubstituted nanocrystalline $\mathrm{TiO}_{2}$ photoanodes for perovskite based heterojunction solar cells," Nanoscale, vol. 6, no. 3, pp. 1508-1514, 2014.

[23] W.-Q. Wu, F. Huang, D. Chen, Y.-B. Cheng, and R. A. Caruso, "Thin films of dendritic anatase titania nanowires enable effective hole-blocking and efficient light-harvesting for high-performance mesoscopic perovskite solar cells," Advanced Functional Materials, vol. 25, no. 21, pp. 3264-3272, 2015.

[24] D.-Y. Son, J.-H. Im, H.-S. Kim, and N.-G. Park, "11\% Efficient perovskite solar cell based on $\mathrm{ZnO}$ nanorods: an effective charge collection system," Journal of Physical Chemistry C, vol. 118, no. 30, pp. 16567-16573, 2014.

[25] H.-S. Kim, J.-W. Lee, N. Yantara et al., "High efficiency solidstate sensitized solar cell-based on submicrometer rutile $\mathrm{TiO}_{2}$ nanorod and $\mathrm{CH}_{3} \mathrm{NH}_{3} \mathrm{PbI}_{3}$ perovskite sensitizer," Nano Letters, vol. 13, no. 6, pp. 2412-2417, 2013.

[26] X. Huang, X. Qi, F. Boey, and H. Zhang, "Graphene-based composites," Chemical Society Reviews, vol. 41, no. 2, pp. 666686, 2012.

[27] X. Huang, Z. Zeng, Z. Fan, J. Liu, and H. Zhang, "Graphenebased electrodes," Advanced Materials, vol. 24, no. 45, pp. 59796004, 2012.

[28] I. V. Lightcap and P. V. Kamat, "Graphitic design: prospects of graphene-based nanocomposites for solar energy conversion, storage, and sensing," Accounts of Chemical Research, vol. 46, no. 10, pp. 2235-2243, 2013.

[29] J. G. Radich, A. L. Krenselewski, J. Zhu, and P. V. Kamat, "Is graphene a stable platform for photocatalysis? Mineralization of reduced graphene oxide with UV-irradiated $\mathrm{TiO}_{2}$ nanoparticles," Chemistry of Materials, vol. 26, no. 15, pp. 4662-4668, 2014.

[30] J. Liu, Z. Lin, T. Liu et al., "Multilayer stacked low-temperaturereduced graphene oxide films: preparation, characterization, and application in polymer memory devices," Small, vol. 6, no. 14, pp. 1536-1542, 2010.

[31] Q. He, S. Wu, S. Gao et al., "Transparent, flexible, all-reduced graphene oxide thin film transistors," ACS Nano, vol. 5, no. 6, pp. 5038-5044, 2011.

[32] Q. He, H. G. Sudibya, Z. Yin et al., "Centimeter-long and large-scale micropatterns of reduced graphene oxide films: fabrication and sensing applications," ACS Nano, vol. 4, no. 6, pp. 3201-3208, 2010.
[33] Y. H. Ng, I. V. Lightcap, K. Goodwin, M. Matsumura, and P. V. Kamat, "To what extent do graphene scaffolds improve the photovoltaic and photocatalytic response of $\mathrm{TiO}_{2}$ nanostructured films?" Journal of Physical Chemistry Letters, vol. 1, no. 15, pp. 2222-2227, 2010.

[34] N. Yang, J. Zhai, D. Wang, Y. Chen, and L. Jiang, "Twodimensional graphene bridges enhanced photoinduced charge transport in dye-sensitized solar cells," ACS Nano, vol. 4, no. 2, pp. 887-894, 2010.

[35] Z. Yin, S. Sun, T. Salim et al., "Organic photovoltaic devices using highly flexible reduced graphene oxide films as transparent electrodes," ACS Nano, vol. 4, no. 9, pp. 5263-5268, 2010.

[36] J. T.-W. Wang, J. M. Ball, E. M. Barea et al., "Low-temperature processed electron collection layers of graphene/ $/ \mathrm{TiO}_{2}$ nanocomposites in thin film perovskite solar cells," Nano Letters, vol. 14, no. 2, pp. 724-730, 2014.

[37] O. Malinkiewicz, A. Yella, Y. H. Lee et al., "Perovskite solar cells employing organic charge-transport layers," Nature Photonics, vol. 8, no. 2, pp. 128-132, 2014.

[38] B.-E. Cohen, S. Gamliel, and L. Etgar, "Parameters influencing the deposition of methylammonium lead halide iodide in hole conductor free perovskite-based solar cells," APL Materials, vol. 2, no. 8, Article ID 081502, 2014.

[39] L. Etgar, "Hole-transport material-free perovskite-based solar cells," MRS Bulletin, vol. 40, no. 8, pp. 674-680, 2015.

[40] W. S. Hummers Jr. and R. E. Offeman, "Preparation of graphitic oxide," Journal of the American Chemical Society, vol. 80, no. 6, p. 1339, 1958.

[41] A. Lerf, H. He, M. Forster, and J. Klinowski, "Structure of graphite oxide revisited," The Journal of Physical Chemistry B, vol. 102, no. 23, pp. 4477-4482, 1998.

[42] C. Zhang, X. Zhu, Z. Wang et al., "Facile synthesis and strongly microstructure-dependent electrochemical properties of graphene/manganese dioxide composites for supercapacitors," Nanoscale Research Letters, vol. 9, no. 1, article 490, 2014.

[43] A. Shokuhfar, A. Hassanjani-Roshan, M. R. Vaezi, S. M. Kazemzadeh, A. E. Kandjani, and B. Nasiri-Tabrizi, "Synthesis and characterization of $\mathrm{TiO}_{2}$ nanoparticles via chemical bath deposition (CBD) method," Journal of Nano Research, vol. 11, pp. 35-38, 2010.

[44] H. Zhang, P. Xu, G. Du et al., "A facile one-step synthesis of $\mathrm{TiO}_{2}$ /graphene composites for photodegradation of methyl orange," Nano Research, vol. 4, no. 3, pp. 274-283, 2011.

[45] S. G. Pawar, S. L. Patil, M. A. Chougule, A. T. Mane, D. M. Jundale, and V. B. Patil, "Synthesis and characterization of polyaniline: $\mathrm{TiO}_{2}$ nanocomposites," International Journal of Polymeric Materials and Polymeric Biomaterials, vol. 59, no. 10, pp. 777-785, 2010.

[46] H. Zhou, Q. Chen, G. Li et al., "Interface engineering of highly efficient perovskite solar cells," Science, vol. 345, no. 6196, pp. 542-546, 2014.

[47] J. You, Z. Hong, T.-B. Song et al., "Moisture assisted perovskite film growth for high performance solar cells," Applied Physics Letters, vol. 105, no. 18, Article ID 183902, 2014.

[48] J.-Y. Jeng, Y.-F. Chiang, M.-H. Lee et al., " $\mathrm{CH}_{3} \mathrm{NH}_{3} \mathrm{PbI}_{3}$ perovskite/fullerene planar-heterojunction hybrid solar cells," Advanced Materials, vol. 25, no. 27, pp. 3727-3732, 2013.

[49] H.-B. Kim, H. Choi, J. Jeong et al., "Mixed solvents for the optimization of morphology in solution-processed, invertedtype perovskite/fullerene hybrid solar cells," Nanoscale, vol. 6, no. 12, pp. 6679-6683, 2014. 
[50] J. Burschka, N. Pellet, S.-J. Moon et al., "Sequential deposition as a route to high-performance perovskite-sensitized solar cells," Nature, vol. 499, no. 7458, pp. 316-319, 2013.

[51] L. Bertoluzzi, P. P. Boix, I. Mora-Sero, and J. Bisquert, “Theory of impedance spectroscopy of ambipolar solar cells with trapmediated recombination," The Journal of Physical Chemistry $C$, vol. 118, no. 30, pp. 16574-16580, 2014.

[52] F. Fabregat-Santiago, J. Bisquert, G. Garcia-Belmonte, G. Boschloo, and A. Hagfeldt, "Influence of electrolyte in transport and recombination in dye-sensitized solar cells studied by impedance spectroscopy," Solar Energy Materials and Solar Cells, vol. 87, no. 1-4, pp. 117-131, 2005.

[53] I. Mora-Seró, G. Garcia-Belmonte, P. P. Boix, M. A. Vázquez, and J. Bisquert, "Impedance spectroscopy characterisation of highly efficient silicon solar cells under different light illumination intensities," Energy and Environmental Science, vol. 2, no. 6, pp. 678-686, 2009.

[54] I. Mora-Seró, Y. Luo, G. Garcia-Belmonte et al., "Recombination rates in heterojunction silicon solar cells analyzed by impedance spectroscopy at forward bias and under illumination," Solar Energy Materials and Solar Cells, vol. 92, no. 4, pp. 505-509, 2008.

[55] J. Bisquert, E. Palomares, and C. A. Quiñones, "Effect of energy disorder in interfacial kinetics of dye-sensitized solar cells with organic hole transport material," The Journal of Physical Chemistry B, vol. 110, no. 39, pp. 19406-19411, 2006.

[56] F. Fabregat-Santiago, G. Garcia-Belmonte, I. Mora-Seró, and J. Bisquert, "Characterization of nanostructured hybrid and organic solar cells by impedance spectroscopy," Physical Chemistry Chemical Physics, vol. 13, no. 20, pp. 9083-9118, 2011.

[57] R. S. Sanchez, V. Gonzalez-Pedro, J.-W. Lee et al., "Slow dynamic processes in lead halide perovskite solar cells. Characteristic times and hysteresis," Journal of Physical Chemistry Letters, vol. 5, no. 13, pp. 2357-2363, 2014.

[58] E. J. Juarez-Perez, M. Wußler, F. Fabregat-Santiago et al., "Role of the selective contacts in the performance of lead halide perovskite solar cells," Journal of Physical Chemistry Letters, vol. 5, no. 4, pp. 680-685, 2014.

[59] C. Eames, J. M. Frost, P. R. F. Barnes, B. C. O’Regan, A. Walsh, and M. S. Islam, "Ionic transport in hybrid lead iodide perovskite solar cells," Nature Communications, vol. 6, article 7497, 2015.

[60] E. L. Unger, E. T. Hoke, C. D. Bailie et al., "Hysteresis and transient behavior in current-voltage measurements of hybridperovskite absorber solar cells," Energy and Environmental Science, vol. 7, no. 11, pp. 3690-3698, 2014.

[61] A. R. Pascoe, N. W. Duffy, A. D. Scully, F. Huang, and Y.B. Cheng, "Insights into planar $\mathrm{CH}_{3} \mathrm{NH}_{3} \mathrm{PbI}_{3}$ perovskite solar cells using impedance spectroscopy," The Journal of Physical Chemistry C, vol. 119, no. 9, pp. 4444-4453, 2015.

[62] C. Quarti, E. Mosconi, J. M. Ball et al., "Structural and optical properties of methylammonium lead iodide across the tetragonal to cubic phase transition: implications for perovskite solar cells," Energy \& Environmental Science, vol. 9, pp. 155-163, 2016.

[63] L. Cojocaru, S. Uchida, Y. Sanehira et al., "Temperature effects on the photovoltaic performance of planar structure Perovskite solar cells," Chemistry Letters, vol. 44, no. 11, pp. 1557-1559, 2015.

[64] S. M. Gupta and M. Tripathi, "A review of $\mathrm{TiO}_{2}$ nanoparticles," Chinese Science Bulletin, vol. 56, no. 16, pp. 1639-1657, 2011.
[65] A. Fujishima, T. N. Rao, and D. A. Tryk, "Titanium dioxide photocatalysis," Journal of Photochemistry and Photobiology C: Photochemistry Reviews, vol. 1, no. 1, pp. 1-21, 2000.

[66] S. Ito, S. Tanaka, K. Manabe, and H. Nishino, "Effects of surface blocking layer of $\mathrm{Sb}_{2} \mathrm{~S}_{3}$ on nanocrystalline $\mathrm{TiO}_{2}$ for $\mathrm{CH}_{3} \mathrm{NH}_{3} \mathrm{PbI}_{3}$ perovskite solar cells," The Journal of Physical Chemistry C, vol. 118, no. 30, pp. 16995-17000, 2014.

[67] T. Leijtens, G. E. Eperon, S. Pathak, A. Abate, M. M. Lee, and H. J. Snaith, "Overcoming ultraviolet light instability of sensitized $\mathrm{TiO}_{2}$ with meso-superstructured organometal trihalide perovskite solar cells," Nature Communications, vol. 4, article 2885, 2013.

[68] S. Guarnera, A. Abate, W. Zhang et al., "Improving the longterm stability of perovskite solar cells with a porous $\mathrm{Al}_{2} \mathrm{O}_{3}$ buffer layer," The Journal of Physical Chemistry Letters, vol. 6, no. 3, pp. 432-437, 2015.

[69] S. K. Pathak, A. Abate, T. Leijtens et al., "Towards long-term photostability of solid-state dye sensitized solar cells," Advanced Energy Materials, vol. 4, no. 8, Article ID 1301667, 2014.

[70] L.-W. Zhang, H.-B. Fu, and Y.-F. Zhu, "Efficient $\mathrm{TiO}_{2}$ photocatalysts from surface hybridization of $\mathrm{TiO}_{2}$ particles with graphitelike carbon," Advanced Functional Materials, vol. 18, no. 15, pp. 2180-2189, 2008.

[71] J. Xu, A. Buin, A. H. Ip et al., "Perovskite-fullerene hybrid materials suppress hysteresis in planar diodes," Nature Communications, vol. 6, article 7081, 2015.

[72] Y. Shao, Z. Xiao, C. Bi, Y. Yuan, and J. Huang, "Origin and elimination of photocurrent hysteresis by fullerene passivation in $\mathrm{CH}_{3} \mathrm{NH}_{3} \mathrm{PbI}_{3}$ planar heterojunction solar cells," Nature Communications, vol. 5, article 5784, 2014.

[73] G. Xing, N. Mathews, S. S. Lim et al., "Low-temperature solution-processed wavelength-tunable perovskites for lasing," Nature Materials, vol. 13, no. 5, pp. 476-480, 2014.

[74] G. Xing, B. Wu, S. Chen et al., "Interfacial electron transfer barrier at compact $\mathrm{TiO}_{2} / \mathrm{CH}_{3} \mathrm{NH}_{3} \mathrm{PbI}_{3}$ heterojunction," Small, vol. 11, no. 29, pp. 3606-3613, 2015.

[75] A. K. Jena, H.-W. Chen, A. Kogo, Y. Sanehira, M. Ikegami, and T. Miyasaka, "The interface between FTO and the $\mathrm{TiO}_{2}$ compact layer can be one of the origins to hysteresis in planar heterojunction perovskite solar cells," ACS Applied Materials and Interfaces, vol. 7, no. 18, pp. 9817-9823, 2015. 

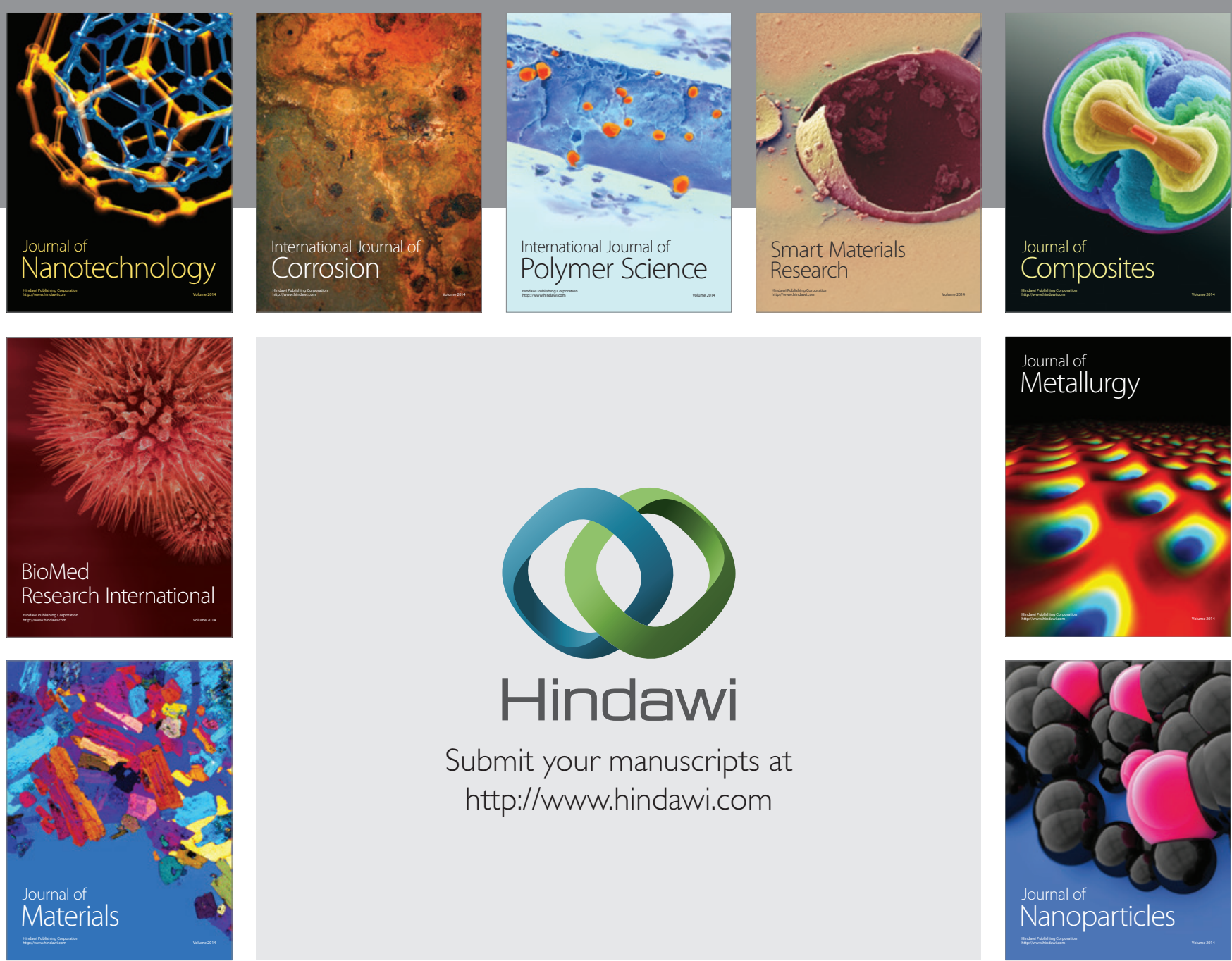

\section{Hindawi}

Submit your manuscripts at

http://www.hindawi.com

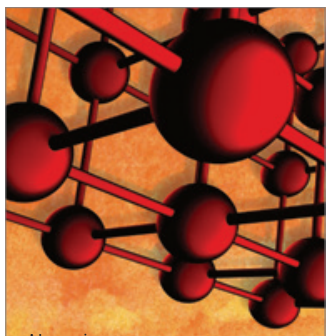

Materials Science and Engineering
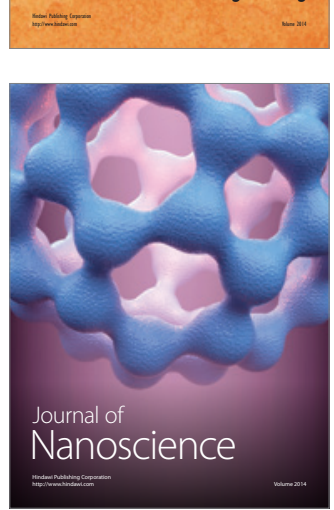
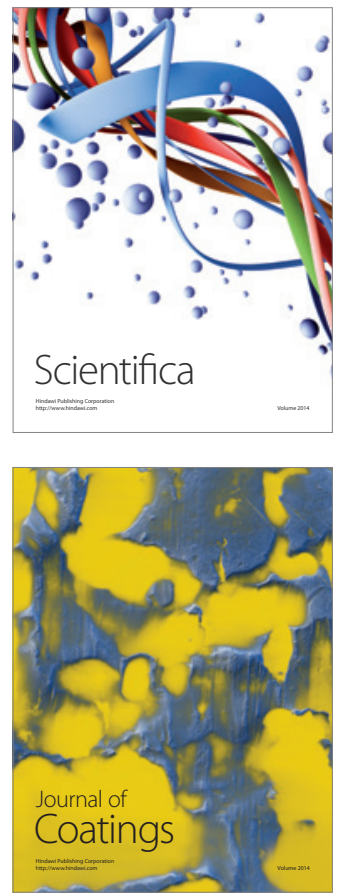
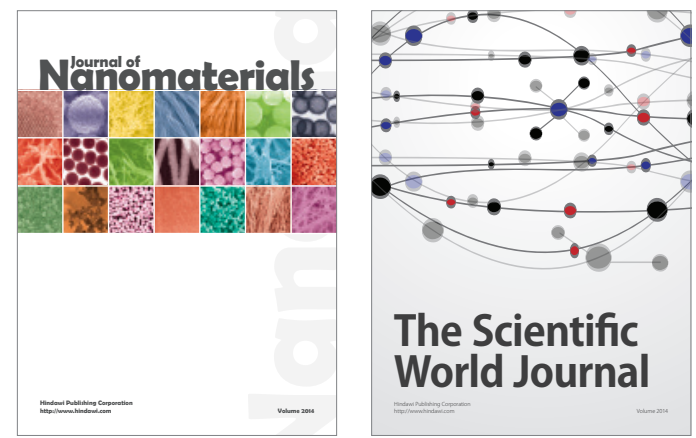

The Scientific World Journal
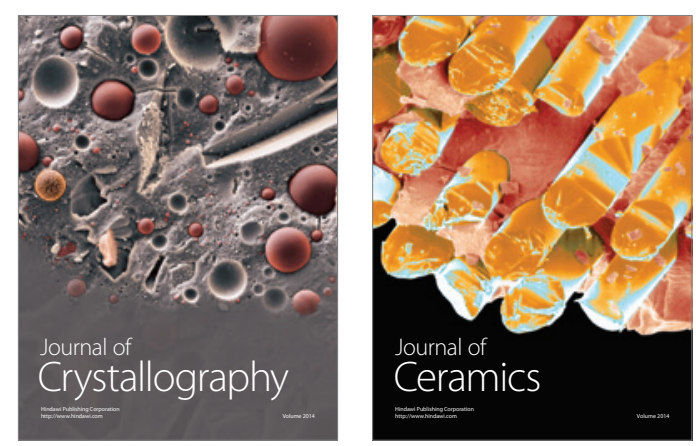
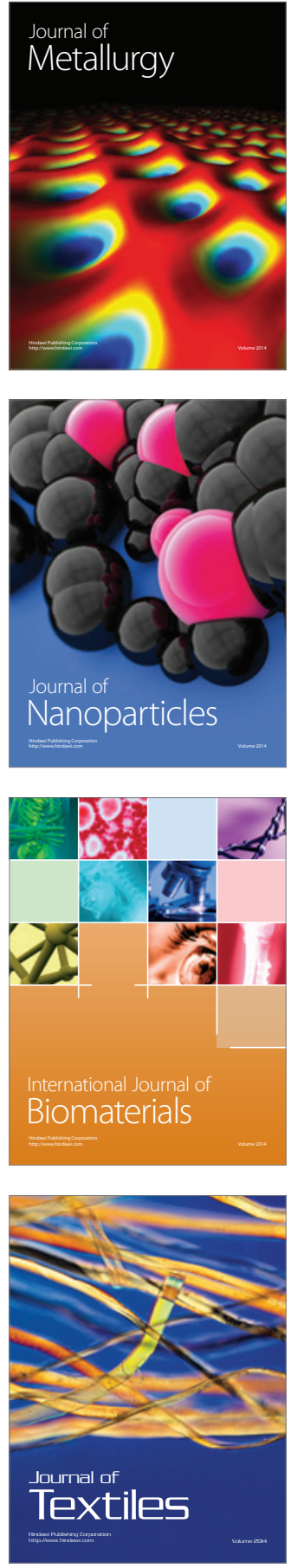